\title{
LATIN AMERICA AS A KEY-COMPONENT OF THE SPANISH CULTURAL POLICY IN THE 20TH CENTURY
}

\author{
Katerina Papaioannou \\ University of Patras, GREECE, papaioannou.kat@gmail.com
}

\begin{abstract}
This study aims at highlighting the role of Latin America in the context of the development of the cultural strategy of Spain in the 20th century. Latin America was a key area for the development of the Spanish cultural policy mainly due to elements having linked the two countries in the past. In what follows, we present the course of significant actions of Spain since the beginning of the 20th century, such as the establishment of the "Columbus day" ("Día de la raza") and the action of the Institute of Spanish Culture during the Franco regime. Our aim is to understand and analyze the relationship between Spain and Latin America and investigate how this relationship was exploited by Spain for the organization and implementation of the Spanish cultural strategy at an international level.

During the 20th century, Spain worked towards the creation of a cluster containing all Spanish-speaking countries, since language was identified as an important element unifying peoples. In order to regain its strength in international politics, Spain had to work in a coordinated way and efficiently exploit factors of significant cultural potential, such as language. In terms of culture, Latin America was the space most closely connected to Spain. Therefore, the initial phase of the development of the Spanish cultural strategy was heavily based on the exploitation of the strong cultural bonds between Spain and Latin America.

In this context, we present a detailed analysis on the role of the relationship of Spain with Latin America, we investigate how Spain exploited Latin America for implementing its cultural strategy and discuss whether the Spanish approach succeeded in the promotion of the Spanish cultural heritage at an international level.
\end{abstract}

Keywords: Cultural policy, Spain, Latin America.

\section{INTRODUCTION}

During the 20th century, Spain and the respective leaders were convinced of the need for cultural strategy, its usefulness and the particular potential that could develop at an international level. Not surprisingly, Latin America was a primary growth area for the Spanish cultural strategy because of the plethora of elements linking the two countries in the past. During the first decades of the 20th century, October 12 was established in Latin America as the day of the official celebration of the arrival of Christopher Columbus in America. The celebration of the "Columbus day" ("Día de la raza"), which flagged the official recognition of the Spanish 
roots of all nations in the region, reflects the shared interest of Spain and Latin American countries to establish closer links between them, albeit for different reasons on each side.

During the 20th century, Spain worked towards the creation of a cluster containing all Spanish-speaking countries, since language was identified as an important element unifying peoples. In order to regain its strength in international politics, Spain had to work in a coordinated way and efficiently exploit factors of significant cultural potential, such as language. In terms of culture, Latin America was the space most closely connected to Spain. Therefore, the initial phase of the development of the Spanish cultural strategy was heavily based on the exploitation of the strong cultural bonds between Spain and Latin America.

In the following section, we trace the connection between Spain and Latin America and investigate whether Spain used this connection in order to organize and apply its cultural strategy at an international level. In particular, in this context, we present a detailed analysis on the role of the relationship of Spain with Latin America, we investigate how Spain exploited Latin America for implementing its cultural strategy and discuss whether the Spanish approach succeeded in the promotion of the Spanish cultural heritage at an international level.

\section{SPAIN AND LATIN AMERICA: A MULTI-PURPOSE DECISIVE POLICY}

Spain, although having lost its former leading role on the international scene, was seeking new ways to recover and - why not - regain lost ground. Latin America, wishing to declare its opposition to the growing US expansionism, decided to tighten political, economic and cultural bonds with Spain. The celebration of the "Columbus day" officially started in all Latin American states in the 1910s and 1920s aiming to highlight the close bonds between the nation "discovered and civilized" by Spain and nations created afterwards in the American continent.

This was the result of a policy of Spain that had begun much earlier but remained active, sometimes more strongly, sometimes to a less intense degree, throughout the 20th century. Regardless of the current political situation, Spain never forgot the importance of Latin American countries. Even in times of international isolation, Latin America was the first tracing point for supporters.

During the Franco regime, the Institute of Spanish Culture (Instituto de Cultura Hispánica (ICH)) had been active seeking allies in international politics. Initially, it turned to Latin America in order to gain the support of right-wing political groups and the Catholic and conservative social circles. The main concern was to "make friends at all costs", especially among circles that could influence international organizations, the press, universities and the Foreign Ministries of Latin America. Particular emphasis was given to personal contacts, invitations and awards.

Elements composing the cultural strategy of that period were intended to show the strong interest of Spain for Latin America as well as, vice versa, to attract the interest of Latin America for Spain, an interest that would be manifested in a number of respective ways.

Typical example is the publication of various collections of books and journals (e.g., "Mundo Hispánico y Cuadernos Hispanoamericanos") which tackled various issues of this particular community of nations (González Casasnovas, 2003). Equally important initiative was the creation of Spanish libraries and the introduction of annually-awarded prizes to books, articles and films. Furthermore, the award of scholarships to students and priests from Latin America was also maintained. At the same time, personal and professional contacts were promoted through invitations for visiting Spain to journalists, academics, leading figures of Latin America from the political and religious stage (Gómez-Escalonilla, 1988, p. 109-227).

The creation of branches of the Institute of Spanish Culture in states of Latin America was actively supported. In fact, the presence of the Institute of Spanish Culture proved particularly useful for Spain to reach potential allies and gradually pave the way for the elimination of international condemnation of the United Nations. Simultaneously, the presence of the Institute of Spanish Culture helped to present the Spanish dictatorship as a global and anti-communist firewall, in a world increasingly affected by the bipolar confrontation. Intensifying cultural relations also contributed to the restoration of ties with organizations of Spanish immigrants, preventing them from nuclei of exiled Spanish groups having their origins to the opposition. Equally important was the role of the Institute of Spanish Culture in the domestic political scene. The Institute of Spanish Culture was presented to the public, via media controlled by the regime, as a substitute for external recognition (Rein, 1995).

In 1953, when international isolation was overcome, the idea of grouping all Spanish-speaking countries in a joint project, the Hispanic Community of Nations, was launched. Spain, with an eye to this process of convergence, sought a concerted action within international organizations. Spain also collaborated with two other organizations, the United Nations Economic Commission for Latin America and the Caribbean 
(Comisión Económica para América Latina y el Caribe (CEPAL)) and the Organization of American States (Organización de los Estados Americanos (OEA)) , through participation in technical assistance programs. Simultaneously, negotiations were held on legal texts relating to dual citizenship, immigration and social security agreements, cultural agreements or broader peace and friendship agreements (Herrero, Tabanero, 1993, p. 120-160).

With an objective towards a perspective to convergence, the Institute of Spanish Culture showed particular interest in the professional and technical training for stakeholders coming from Latin American countries, such as doctors, lawyers, engineers, academics, union leaders, journalists, etc. This action was intended to create a pro-Spanish core in the ruling elites of Latin American countries. This course of action as well as personal and institutional contacts created due to this action formed a complementary tool to strengthen the political content of this cultural action. Spanish leaders maintained the vision that they could continue their activities in Latin America as a former colonial metropolis of the old colonial world.

These ambitious plans collided with the harsh reality of a declining economic budget, which led to reduction of interest on behalf of Latin America towards the potential of external collaboration and, in particular, towards collaboration with Spain. Moreover, there was a credibility problem for the Spanish capacity, since these new proposals were originating from a country actually absent from regional groups, like, for example, the European community. Furthermore, there was lack of reciprocity in organized activities, since they were mainly of unilateral interest, with a direction from Spain to Latin America. Despite all these organized actions on behalf of Spain, the effect of the portion opposed to Franco continued to remain strong (Arenal, 2011).

However, Franco's foreign policy was formed mainly after the 50 s and had as key points of reference the USA and Western Europe. This range of priorities was formulated even more clearly after the $60 \mathrm{~s}$, both because of the existence of interest in maintaining strategic relationship with American power and also due to the existence of economic integration in Europe. The foreign policy followed by the Franco regime towards the United States of America and Western Europe was unique and special, completely adapted to the elements indicated by the general circumstances of the period.

\section{CONCLUDING REMARKS}

In conclusion, the foreign policy of Franco regarding Latin America was determined on the basis of the current period but also taking into account elements of the past. Making a brief comparison between the foreign policy followed and applied by the Franco government in the cases of (i) Latin America and (ii) USA and Western Europe, we can conclude that in the former case, the Spanish policy was based on the promotion while in the latter case, it was based on acceptance. In any case, Latin America was a fixed point for the development of the Spanish policy, since Latin America was connected with Spain through major cultural bonds. The existence of a common language and religion were recognized by all political regimes as important elements that could constitute a solid basis for the development of a properly designed foreign policy.

\section{REFERENCE LIST}

Andres, C. G., Casanova, J. (2009). Historia de España en el siglo XX, edit. Ariel, Barcelona.

Del Arenal, C. (2011). Política exterior de España y relaciones con América Latina, edit. Fundación Carolina, Madrid.

Gómez Escalonilla, L. D. (1988). Diplomacia franquista y política cultural hacia Iberoamérica 1939-1953, edit. CSIC, Madrid.

González Casasnovas, I. (2003). La huella editorial del Instituto de Cultura Hispánica, edit. Ministerio de Asuntos Exteriores-Fundación Mapfre Tavera, Madrid.

Pérez Herrero, P., Tabanera, N. (1993). España/América Latina: Un siglo de políticas culturales, edit. AIETIOEI, Madrid.

Rein, R. (2016). La salvación de una dictadura. Alianza Franco-Perón 1946-1955, edit. CSIC, Madrid. 